U.S. DEPARTMENT OF THE INTERIOR

U.S. GEOLOGICAL SURVEY

\title{
GEOLOGIC MAP OF THE HYGIENE QUADRANGLE, BOULDER COUNTY, COLORADO
}

By Richard F. Madole, William A. Braddock, and Roger B. Colton

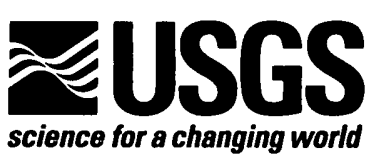

GEOLOGIC QUADRANGLE MAP

Published by the U.S. Geological Survey, 1998

ISBN $060788367-7$

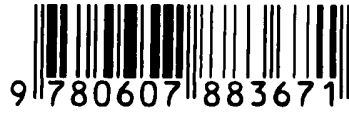

